\title{
The Destructive Effect of the 1937 Amendment of Section 42 of the Pro- bate Code of California Upon the Limitations Regarding Testamen- tary Dispositions to Charity
}

$T_{\text {HE }}$ recent 1937 amendment to section 42 of the Probate Code of 1 California, which provides that bequests and devises to corporations organized under section 606 of the Civil Code are excepted from the restrictions of the article dealing with gifts to charity, seenis to have a very far-reaching and destructive effect upon all the restraints as to time and amount of testamentary bequests and devises to charitable or benevolent societies or corporations, as set forth in section 41 of the Probate Code. This amendment also appears to render the classifications and distinctions of sections 27 and 43 of the Probate Code totally unnecessary, and to produce a marked incongruity in our law, capable of generating a mass of curious technicalities that cannot possibly serve any useful purpose.

By the provisions of section 41 of the Probate Code, a testator bequeathing or devising to any charitable or benevolent society or corporation, or to any person or persons in trust for charitable uses, must make his will at least thirty days prior to death, and nuay not leave to such beneficiary or beneficiaries, niore than one-third of his estate, if he is survived by a spouse, brother, sister, nephew, mece, descendant or ancestor. Section 27 of the Probate Code lists various types of corporations and associations which may take by will. Section 42 of the Probate Code exenipts from the restrictions set forth in section 41 , the sovereign State of Cahifornia, mumicipalities, and pohtical subdivisions, institutions of the state or of municipalities, educational institutions exempt from taxation under the state constitution, and now, by the recent 1937 amendment all corporations organized under section 606 of the Civil Code. This section provides that twenty-five or more persons may organize a non-profit corporation for the purpose of receiving, acquiring, holding, managing, administering and expending property and funds for charitable and eleemosynary purposes, and authorizes such a corporation to act as trustee under charitable trusts. It seems, therefore, under the 1937 amendment to section 42 of the Probate Code, that if a testator leaves his property to this type of corporation, to hold for the true beneficiary in interest, which is incapable of taking the property directly, except subject to the restrictions of section 41 of the Probate 
Code, he can successfully avoid them. This amendment is indeed an amazing evolution of the legislature, an authorization to do indirectly what one is prohibited from doing directly, a law that lacks even a scintilla of reason. Careful analysis of our statutes on this subject and of the decisions interpreting them, discloses that they were enacted for the supposed protection of the heirs-at-law of a testator, in order that he might not give by will, at a time too close to his death, an undue amount to charity. ${ }^{1}$ It should be noted, however, that the legislature left open to the donor, the revocable deed or death bed deed, a means equally simple and effective, of accomplishing the very purpose which he was forbidden to accomplish by will. ${ }^{2}$ When we consider this in conjunction with the fact that we have never had in California any Statutes of Mortmain or any Mortmain Policy, ${ }^{3}$ it is impossible to see how section 41 of the Probate Code could ever liave effectively served its own purpose, i.e., the protection of the heirs-at-law, or any other beneficial purpose.

Since the 1937 amendment of section 42 of the Probate Code has injected such highly artificial and technical elements into the law of charitable bequests and devises, and has made of it a trap for the innocent, unwary donor, the only adequate and practical means of solving the mass of vague and uncoordinated legislation on cliaritable bequests and devises in California would appear to lie in a complete and unqualified repeal of all the statutes we lave just been discussing. Before passing, however, to the consideration of this problem, a full solution of which is impossible without first establishing certain fundamental premises, it seems wise at the outset to investigate our earlier statutes from whicl these later ones lave been derived, to determine what, if anything, they have in common with the law of England on this subject, and to study the causes which led to their enactment.

As the policy which prompts the passage of laws is one of the most important factors in the determination of their meaning and for the reason that former sections 1275 and 1313 of the Civil Code of Califorma, parent sections of sections 27, 41, 42 and 43 of the Probate Code, seem to bear some superficial resemblance to certain of the so-called English Statutes of Mortmain, with which they are at times confused, it will be necessary, in order to treat intelligently the problem involved in the title of this article to consider:

1. The history of the Statutes of Mortmain.

2. The purposes of the Statutes of Mortmain.

3. The Mortmain Policy in the United States, a. In general; b. In Califorma.

1 Estate of Dwyer (1911) 159 Cal. 680, 115 Pac. 242.

2 President etc. of Bowdoin College v. Merritt (N.D. Cal. 1896) 75 Fed. 480.

3 Estate of Dwyer, supra note 1. 
4. The confusion of Statutes of Mortmain with statutes himiting the dispository powers of testators,
a. In England;
b. In the United States fornia.

5. The history of former section 1275 of the Civil Code ${ }^{4}$.

6. The history of former section 1313 of the Civil Code ${ }^{5}$.

7. Lawful neans of giving to charitable organizations, regardless of restrictions of former section 1313 of the Civil Code and of section 41 of the Probate Code.

8. The inutility of former sections 1275 and 1313 of the Civil Code or of similar sections of the Probate Code.

9. The present status of the law by reason of the 1937 amendment to section 42 of the Probate Code.

\section{THE HISTORY OF THE STATUTES OF MORTMATN}

At common law all corporations had the capacity to purchase lands for themselves and successors. By a great variety of statutes this privilege of purchasing lands was greatly abridged, and it was provided that a corporation in order to exert the capacity vested in it by the common law must first obtain a license from the king in order to purchase. Statutes of this type are generally called Statutes of Mortmain, and purcliases by corporate bodies under these statutes are termed purchases in Mortmain, i.e., in mortua manu. ${ }^{6}$

Although Blackstone says such licenses of Mortmain seem to have been necessary among the Saxons, above 60 years before the Norman Conquest, ${ }^{7}$ most authorities generally refer to 9 Henry IIII ${ }^{8}$ as the first of the Mortmain Statutes. The language of this statute is pertinent:

\footnotetext{
"It shall not be lawful from henceforth to any to give his Lands to any Religious House, and to take the same Land again to hold of the same House. Nor shall it be lawful to any House of Religion to take the Lands of any, and to lease the same to him of whom he received it. If any from henceforth give his Lands to any Rehgious House, and thereupon be convict, the Gift shall be utterly void, and the Land shall accrue to the Lord of the Fee."
}

Following this first Statute of Mortmain some twelve others were passed which we shall consider in their chronological order.

1. The statute $D e$ Religiosis, ${ }^{9}$ which is auxiliary to the statute of

\footnotetext{
${ }^{4}$ See Car. Prob. Code § 27.

- See Cal. Prob. Code $\$ 41$ et seq.

${ }^{6}$ Cf. I Bc. Comms. (Jones ed. 1915) *479.

7 Selden, Jan. Angl. 1.2, \& 45.

89 HEN. III (1225) c. 36. Italics added.

97 Edw. I (1279) St. 2.
} 
Henry III, and makes similar provisions applicable to persons attempting to buy, sell or receive lands in Mortmain.

2. The statute of Westminster $\Pi^{10}$ provides for trial of these cases by jury, etc.

3. The statute Quia Emptores ${ }^{11}$ provided that its terms should not be extended to any kind of alienation in Mortmam.

4. The statute 27 Edward $I^{12}$ provided the method of obtaining the King's license by the writ ad quod damnum.

5. The statute 34 Edward $I^{13}$ provided that the King might not issue an effectual license in Mortmain without consent of the mesne lords.

6. The statute $18 \mathrm{Edward} \mathrm{II}^{14}$ was merely declaratory and confirmatory of the King's right to grant licenses in Mortmain and to remit forfeitures.

7. The statute 15 Richard $\Pi^{15}$ provided that lands purchased to uses be amortized by hicense from the Crown or sold to private persons and that uses shall for the future be subject to the Statutes of Mortmain and forfeitable like lands themselves.

8. The statute 23 Henry VIII ${ }^{16}$ extended the Mortmain policy to lands made hable to the charge of obits, chantries and the like.

9. In 1554 the Statutes of Mortmain were suspended for a period of twenty years. ${ }^{17}$

10. The statute 17 Charles $\Pi^{18}$ further relaxed the Mortmain policy.

11. Statute 7 and 8 William III $^{19}$ allowed the Crown in its own discretion to grant licenses to alien or take in Mortmain, the rights of lords laving become much reduced through the long application of the statute Quia Emptores.

12. Statutes 2 and 3 Anne $^{20}$ further relaxed the Mortmain policy. A thirteenth statute called The Mortmain and Charitable Uses Act ${ }^{21}$ will be noted hereafter.

A few years before the passage of the eighth statute above listed,22 public policy in England went through very radical changes due to differences in religious behefs. Most of the existing confusion about Statutes

1013 EDw. I (1285) c. 32.

1118 EDw. I. (1290) St. 1, c. 3.

1227 EDw. I (1298) St. 2.

1334 EDw. I (1306) St. 3.

1418 EDw. III (1344) St. 3, c. 3.

1515 RICE. II (1391) c. 5.

1623 HEN. VIII (1531) c. 10.

171 \& 2 P. \& M. (1554) c. 8.

1817 CAR. II (1665) c. 3.

197 \& 8 WM. III (1696) c. 37.

202 \& 3 ANNE (1703) c. 11.

$2151 \& 52$ VICT. (1888) c. $42, \llbracket 1$.

22 Supra note 16. 
of Mortmain may be traced to this period, when the great schism with Rome began and certain so-called Statutes of Mortmain were enacted to aid in the confiscation of lands of monasteries and convents and to strengthen an anti-papal policy destined to be reflected both directly and indirectly in much of the English legislation for three centuries.

\section{THE PURPOSES OF THE STATUTES OF MORTMAIN}

One of the principal reasons alleged for the earher Statutes of Mortmain is that when corporations began to acquire much land it was observed that the feudal services ordained for the defense of the kingdom were everyday visibly withdrawn and that the circulation of landed property from man to man diminished and that the Lords were curtailed of the fruits of their seigniories, their escheats, wardships, reliefs, and the like. ${ }^{23}$

Since these rights incident to tenure formed at that time one of the most iniportant parts of the great land barons' revenues, it is very easy to see why jealous nobles and kings wished to prevent bodies corporate fron acquiring lands in England, and so directed their legislation against the church, the ouly corporation at the time, of any prominence. This is also further evidenced by the statutes which required the hicense of the particular mesne lord as well as that of the king in order to effect a purchase in Mortnain. ${ }^{24}$

"The word mortmain is a transcription rather than translation of the Latin manus mortua, a term probably used, as Mr. Digby suggests, because the regular clergy against whose endowment this legislation was chiefly directed were treated for legal purposes as dead, 'civiliter inortui.' Coke's explanation (after mentioning two or three wild ones 'framed out of wit and invention') is that 'the lands were said to come to dead-hands as to their lords, for that by alienation in mortmain they lost wholly their escheats, and in effect their knight-services for the defense of the realm, wards, marriages, reliefs, and the like; and therefore [it] was called a dead hand, for that a dead hand yieldeth no service.' Whatever be its exact derivation, the expression was felt to be forcible and appropriate, and has passed into common speech." 25

"The disabihity of corporations to hold real property was created by various statutes before $34 \mathrm{Hen}$. VIII, which appear to have been founded on the principle, that, by allowing lands to beconie vested in objects endued with perpetuity of duration, the lords were deprived of escheats, and other feudal profits. Hence, the necessity of obtaining the king's

232 Br. Conar. (Jones ed. 1915) *270.

24 Supra note 13.

25 Pozrock, Land Laws (2d ed. 1887) 90. Last italics added. 
license, he being the ultimate lord of every fee in the kingdom; but this license only remitted his own rights, and did not prevent the right of forfeiture accruing to intermediate lords." 26

\section{THE MIORTMAIN POLICY IN THE UNITED STATES}

a. In general. Whatever may liave been the original Mortmain policy in England, and into whatever it may lave become metamorphosed by reason of religious prejudices, hatred, and persecution under the Tudor sovereigns and some of their successors, Statutes of Mortmain, founded on the customs of a remote past when feudal tenure was fostered as a pet policy of the kingdom, and the rights incident thereto carefully guarded both by rulers and by jealous nobles, cannot be deemed to have been accepted in the Umited States, except perhaps in Pennsylvania, ${ }^{27}$ and there only because William Penn's cliarter was understood as embracing and adopting them. ${ }^{2 \pi a}$ Cliancellor Kent says of these statutes: ${ }^{28}$

"We have not in this country re-enacted the statutes of mortmain, or generally assumed them to be in force; and the only legal check to the acquisition of lands by corporations consists in those special restrictions con-

1 tained in the acts by which they are incorporated, and which usually confine the capacity to purchase real estate to specified and necessary objects; and in the force to be given to the exception of corporations out of the statute of wills, which declares that all persons, other than bodies politic and corporate, may be devisees of real estate."

In Perin v. Carey ${ }^{29} \mathrm{Mr}$. Justice Wayne says:

"...the English Statutes of Mortmain were never in England supposed to have been meant to extend to her colonies, and were never in force in those of them in America which became independent states, but by legal enactment." 30

b. In California. Under modern law, restrictions on corporations acquiring land either by purchase or by devise, liave generally been lifted, and they now liave the same or even a greater capacity in this-regard than they formerly luad at common law. Thus we find in California Corporation Laws by Ballantine: ${ }^{31}$

261 JARMaAN, Wirts (6th Am. ed. 1893) 88.

$2 \pi 3$ Tiffany, Reat Property (2d ed. 1920) 2348, where it is said: "The common-law right of a corporation to acquire land was greatly circumscribed by the enactment of the various statutes of 'mortmain', which, while directed chiefly at ecclesiastical bodies, applied in terms to all corporations, and prohibited their acquisition of land without license from the crown, and during certain periods, from the mesne lords also. These statutes appear to have been adopted in but one state [Pennsylvania]."

27 a 2 KeNT Coarar. (14th ed. Gould, 1896) *282.

28 Ibid.

29 (1860) 65 U. S. (24 How.) $465,499$.

30 To the same effect, see Beall v. Fox (1848) 4 Ga. 404; Moore v. Moore (1836)

34 Ky. (4 Dana) 354, 25 Am. Dec. 417.

31 Ballantine, California Corporation laws (1932) 297, \$257. 
"No limitations are placed on the power of a corporation to acquire and hold or dispose of real estate, although the authority of the directors as between themselves and the corporation may be limited to what is fairly incidental to the corporate business. The tendency of state legislation is away from any statutory restriction on the ownership of real estate by corporations organized for business purposes and even the restrictions formerly imposed upon religious and non-profit corporations have been removed."

In support of this statement Professor Ballantine cites in his footnotes sections 597 and 606 of the Civil Code of California.

In section 341 of the Civil Code of Califorma we find the following provision: "Every corporation heretofore or hereafter organized has power: ... (3) To acquire, hold, lease, encumber, convey or otlerwise dispose of real property within or without the State and to take real and/or personal property by will, gift or bequest." 32 If any doubt ever existed, this statute fully dispels it and clearly confirms the court's decision in Estate of Dwyer ${ }^{33}$ to the effect that there are no Mortmain statutes in California and that we have in this state no Mortmain Policy.

\section{THE CONFUSION OF STATUTES OF MORTMAIN WITH STATUTES}

LIMIIING THE DISPOSITYORY POWERS OF TESTATORS

a. In England. Since the passage of the statutes of Henry VIII, to which reference has already been made, ${ }^{34}$ much confusion seems to have existed in the law, between Statutes of Mortmain and statutes placing restraints on testators' powers of disposition. We have already observed that the first Mortnain Statute was passed in 1225, some three centuries before the great schism with the papacy, and over tliree centuries before the passage of the first Statute of Wills. From these facts we must conclude: (1) that the Mortmain Policy was not one originally developed from differences in religion, because until the reign of Henry VIII there was but the one national religion in England; (2) that the true Statutes of Mortmain were not directed against wills, because prior to 1540 there were, generally speaking, no wills of real property in England. The free willing of real property would have been fundamentally opposed to the principles of feudal tenure involving the descent of estates. Indeed, the making of a will is generally considered under English law as a privilege conferred by statute, the first statute granting this privilege being that of 34 Henry VIII..$^{35}$

32 Italics added.

33 Supra note 1 . See text thereto.

34 Text to notes 16 and 22 , supra.

3534 HeN. VIII (1542-1543) c. 5. 
When Henry VIII broke with Rome in 1529, he initiated a very hostile policy towards the ecclesiastical houses in England, proceeding to confiscate the property of monasteries and convents, and to legislate upon matters spiritual in their nature, endeavoring in various ways to destroy the power of the clergy. Such attitude led to an extension of the Mortmain policy which somewhat metamorphosed its original nature and gave to it certain odious characteristics that it had never before possessed. This is one of the reasons why in our present discussion, we have styled some of the English statutes enacted during or subsequent to this period, "so-called Statutes of Mortmain," lest they be confused with the true, original Statutes of Mortmain. ${ }^{36}$

As wè have before observed, the privilege of making a will was first conferred on Enghish subjects by the Statute of Wills. By this statute it was provided that a testator "shall have, full and free liberty, power, and authority to give, dispose, will or devise to any person or persons (except bodies politick and corporate) by his last will and testament in writing, ... as much as in him of right is or shall be ... at his own free will and pleasure." ${ }^{37}$ It is evident from the very language of this statute that a restraint is placed upon a testator's power of disposition. A direct limitation is imposed upon a testator's power to give, as distinguished from a limitation upon the power of a corporation or body politick to take. We must carefully note this point, as much of the confusion about Statutes of Mortmain is perhaps due to a failure to make this distinction, and the very statute from which we have just quoted is frequently referred to and considered as a Statute of Mortmain. One of the results of this confusion is that if a modern statute contains a restraint upon a testator's power of disposition to any type of corporation or association, trading or non-trading, profit or non-profit, charitable or non-charitable, it is immediately identified with the Statute of Wills or witl subsequent similar statutes, and spoken of (by the injudicious) as a Statute of Mortmain.

At this point it seems well to note, in view of certain California statutes which we shall later be considering, that "An English statute, enacted in $1601,{ }^{38}$ enumerated a list of charitable purposes, provided that. the acts of Mortmain should not apply to them, and created a commission to deal with them." ${ }^{33}$ The policy of early times was very favorable towards gifts, even of land for charitable purposes, and the Statute

36 See 23 HEN. VIII (1531) c. 10, text to note 16, supra. Cf. 1 EDw. VI (1547)

c. 14. See text to notes 61-63, infra.

37 Supra note 35 . Italics added.

3843 Extz. (1601) c. 4.

392 PAGE, WILIS (2d ed. 1928) § 1064. 
43 Eliz. c. 4 (1601) which facilitated gifts of this character was held to a authorize testamentary appointments to corporations for charitable uses. ${ }^{40}$

At the beginning of the eighteenth century, however, the policy in England regarding charitable gifts definitely changed, and by the Statute 9 George II, ${ }^{41}$ charitable institutions were not permitted to take anything at all by will but only by deed in the manner set forth in this statute. In speaking of this statute Jarman says: ${ }^{2}$

\begin{abstract}
"Accordingly, the Statute of George II, c. 36 usually, but rather inaccurately called the Statute of Mortmain, enacted that from and after 4th June, 1736, no hereditaments or personal estate to be laid out in the purchase of hereditaments, should be given, conveyed, or settled to or upon any persons, bodies politic or corporate, or otherwise, for any estate or interest whatever, or in any ways charged or encumbered, in trust or for the benefit of any charitable uses whatsoever, unless such gift or settlement . . . be made by deed indented, sealed and delivered in the presence of two credible witnesses, $t$ welve calendar inonths before the death of the donor, including the days of the execution and death, and enrolled in chancery within six months after execution."
\end{abstract}

Section 3 of the statute makes void any gift not perfected according to the act. As Jarman has very clearly said, this statute is usually but inaccurately called a Mortmain act. It is very evident that the statute is not a Mortmain Statute because it does not incapacitate corporations and bodies politic from taking land but rather prescribes the sole and only method available to donors of giving their lands, i.e., by deed indented and enrolled in the chancery, as prescribed by the statute. In Jarman's work on wills under the title of the chapter "Who May Be Devisees or Legatees," we find, speaking of corporations, the following: ${ }^{43}$ "Their incapacity to take land by devise was a consequence of the exception in the statute of Henry VIII, and since the Act I Victoria c. 26 has repealed that statute without reviving the prohibition, they are now as capable of taking by devise as natural persons." We may here observe two things: (1) that the tern "incapacity to take land" is inaccurately used, because the Statute of Henry VIII did not provide that corporations and bodies politic should be denied the capacity to take land but rather that testators should not have the power to give land to them; (2) that although the Act I Victoria repealed the Statute of Henry VIII, without reviving the prohibition, still we must bear in mind the fact that at that time, testators or donors were not at liberty to give to corporations or bodies politic by bequest or devise, but only by deed indented, and enrolled in the chancery according to the earlier enactment, ${ }^{44}$ and that

401 Jararan, Wris (5th Am. ed. 1893) 420. Italics added.

419 GEo. II (1736) c. 36.

421 JarMaA, Wris (5th Am. ed. 1893) 421. Italics added.

$43 \mathrm{Ibid}$. at 182 . Italics added.

449 GEo. II (1736) c. 36. 
this restraint was not lifted until much later during the reign of Victoria. As Jenks says in his Modern Land Law: ${ }^{15}$ "Inasmuch as, previously to 1891, land could not be devised at all for charitable purposes, it is ob. vious that the recent statute ${ }^{40}$ has effected a complete change of policy." This shows how important it is to distinguisl between the capacity to devise and the capacity to take by devise. The denial of the former does not imply the denial of the latter. Thus we find that as early as 1225 the distinction between the capacity to give and the capacity to take was very clearly understood, for the first Statute of Mortmain provides not merely that donors shall not give to rehgious louses but that religious louses shall not receive land.47

In the notes to Jarman on Wills, chapter IX entitled "Restraints on the Testamentary Power," we find this language: ${ }^{48}$

"It may be added that the statutory restriction upon charitable or other corporations taking land in excess of a certain value, is now held to be rather a restriction laid upon the testator than upon the corporation, (especially if it be incorporated, as is usual, in the Statute of Wills)."

This statement refers more directly to statutes in the Umited States, but it evidently calls for the distinction above suggested. In Thompson $v$. Swoope, ${ }^{49}$ Lowrie, C. J., says:

"Where a corporation of another state is generally competent to take and hold land, the prohibition, in their statute of wills, against all devises of lands to corporations, does not prevent them from taking and holding land in this state by devise; for their statute of wills is intended to regulate the testamentary power of their own citizens, not of ours; to define the capacity of testators, not of corporations."

Speaking of the various provisions of the Mortmain and Charitable Uses Act of $1888^{50}$ Jenks says: ${ }^{51}$

"But these provisions of the Act of 1888 have been greatly modified by the amending Act of $1891^{52}$ which authorizes the assurance by Will, of land for charitable purposes, without any restrictions as to amount, date of execution, or formality, other than the formalities required by the Wills Act. ${ }^{53}$ Inasmuch as, previously to 1891 , land could not be devised at all for charitable purposes, it is obvious that the recent statutes have effected a conrplete change of policy." o4

It is evident therefore that the present law in England is very liberal in regard to cliarities, and that the "Mortmain Policy" has been aban-

45 Jenks, Modern Land Law (1889) 292. Italics added.

4654 \& 55 VICT. (1891) c. $73, \$ 5$.

479 HEN. III (1225) c. 36 . See text to note 8 , sitpra.

481 JARMIAN, WIIIS (5th Ain. ed. 1893) 388.

49 (1855) $24 \mathrm{~Pa} .474,480$.

50 Supra note 21.

51 JENKs, loc. cit. supra note 45. Italics added.

52 Supra note 46.

53 Act. I Vict. c. 26 . See text to note 44.

54 See text to notes $43-48$, supra. 
doned, so that a testator may now make an assurance by will of land for charitable purposes in any amount and at any time, and subject only, as Jenks says, to the formalities of the Wills Act.

b. In the United States. America has always been a haven of the persecuted, and those, who in other lands were tortured for their rehious tenets, have largely been responsible for the colomization and development of this country. Freedom of religious belief and worship has been the rule rather than the exception in the United States. This is very clearly slown by the fact that from the beginning, in practically all of our states, rehioious corporations have been able to acquire lands, and few if any distinctions have been made between these and other types of corporations. There has not been a fluctuating policy like that reflected through the Statutes of Mortmain or the so-called Statutes of Mortmain in England. Our policy has been constant and always protective, tolerant and not intolerant, constructive and not destructive. The Mortmain Statutes have never been adopted as such in the United States, except as before pointed out, and whereas some of the states have enacted certain laws that may be said to resemble some of the so-called Mortmain Statutes, they will generally be found to be based on an entirely different policy and to have little, if anything, in common with those of England, unless, perchance, a mere superficial form. The policy that dictates these statutes is a policy calculated to benefit heirs of a decedent, rather than the state, as will more fully appear from what follows.

In State v. Griffith, ${ }^{55}$ Chancellor Johns says: "The mortmain acts did not extend to the Britisly Colomes," and Sir William Grant says of the Statute 9 George $\mathrm{II}^{56}$ in Attorney-General v. Stewart, "57 "that in its causes, obligations, provisions, qualifications and exceptions it is a law wholly English, calculated for purposes of local policy, complicated with local establishments, and incapable, without great incongruity $m$ its effect, of being transported, as it stands, into the code of any other country."

The policy of this country is also very clearly revealed in the Constitution of the United States and in the constitutions of the various states of the Umon, all closely patterned after it, and each guaranteeing to every individual, freedom of religious belief and freedom of religious worship. This imphes the need of freedom in the acquisition and disposition of property, not merely on the part of individuals but also on the part of charitable and religious corporations as well. It is true that there are a few rare instances in which a less enlightened policy has crossed

55 (1847) 2 Del. Ch. 392, 400.

56 Supra note 44.

57 (1817) 2 Mer. 143, 164. 
the ocean, been nurtured in certain clouded minds, and finally found expression in unsound, judicial decision. These, however, are the exceptions, not the rule. For instance, in the so-called "superstitious uses" cases, although the Enghish courts have steadily been abandoning their long hists of prejudiced precedents, ${ }^{58}$ growing out of certain statutes, ${ }^{50}$ occasionally an American court has perhaps indirectly, through subtle distinctions, adhered to them; but such cases are not generally regarded in other jurisdictions as law. ${ }^{60}$

We find In re Tones Will ${ }^{61}$ quoting from Hollis v. Drew Theological Seminary," "It is not against public policy to allow gifts to charitable, benevolent, scientific, or educational institutions. The law allows and encourages such gifts, and those who make them are commended as the benefactors of their race," and from the decision itself, in In re Tones Will, ${ }^{63}$ "The act, therefore, was not conceived in any hostility to such corporations, for, except a man have a wife, child, or parent him surviving, he can give all his estate to such corporations to be served by the act. It is aimed simply at the giving of an undue proportion to charity by will, when certain near relations have, in the opinion of the Legislature, a better claim .... Its theory is not to keep property away fromı charitable corporations ...." ${ }^{64}$

It is of primary importance to consider the policies that have dictated laws, for these policies strongly influence their interpretation and defimitely mold their applications. Where the mere external or superficial forms of laws seem to resemble one another, we must not hastily conclude that they are actually similar laws. No better example of this can be found, perhaps, than in the statutes which we are presently investigating. Our statutes on the particular subject matter under discussion may bear some superficial resemblance to the so-called English Statutes of Mortmain, but in animus and in substance they are fundamentally different. We must not confuse the spirit of a law with its form. Qui haeret in litera haeret in cortice.

c. In California. An excellent example of the confusion existing between the Statutes of Mortmain and those imposing restraints upon the

58 See Bourne v. Keane [1919] A. C. 815, 89 L, J. Rep. 1920.

59 23 HEN. VIII (1531) c. 10; 1 EDw. VI (1547) c. 14.

60 Compare Estate of Lennon (1907) 152 Cal. 327, 92 Pac. 870, 125 Am. St. Rep. 58, Estate of Dwyer, supra note 1, and Estate of Hamilton (1919) 181 Cal. 758, 186 Pac. 587, with the following: Festorazzi v. St. Joseph's Catholic Church (1894) 104 Ala. 327, 18 So. 394, 25 L. R. A. 360, 53 Am. St. Rep. 48; Rhymer's Appeal (1880) 93 Pa. 142, 39 Am. Rep. 736; Note (1822) 9 Am. Dec. 577, 579.

61 (1919) 186 App. Div. 361, 366, 174 N. Y. Supp. 391, 394.

62 (1884) 95 N. Y. $166,172$.

63 Supra note 61 , at 366,174 N. Y. Supp. at 394 . Italics added.

64 Cf. Amherst College v. Ritch (1897) 151 N. Y. 282,45 N. E. 876,37 L. R. A. 305; St. John v. Andrews Institute (1908) 191 N.Y. 254, 83 N. E. 981, 14 Ann. Cas. 708, aff'd sub. nom. Smithsonian Institute v. St. John (1909) 214 U. S. 19. 
dispository powers of testators is found in a much used work on our jurisprudence. Seriously misleading and erroneous statements like the one about to be noticed, are very apt to augment confusion upon points which are in themselves somewhat obscure. Thus, for example, in California Jurisprudence we find the following: 65 "While section 1313 of the Civil Code is derived from the English mortmain statutes ...." Examining the sole decision to which we are referred, President etc. of Bowdoin College v. Merritt ${ }^{66}$ we find absolutely no statement whatever as to the derivation of section 1313 of the Civil Code or as to the derivation of statutes of similar import, from Enghish or other Mortmain Statutes. The scope of this article does not permit of a multiphication of similar instances occurring in other works.

The true policy of the State of Califorma is clearly set forth in Estate of Dwyer: ${ }^{\text {TT }}$

"There is no limitation under the laws of this state, except as prescribed by section 1313 [Civil Code], upon the riglt of a person to dispose of his property in favor of cliaritable purposes. He may by gift in his lifetime devote all his property thereto. He has a legal right to do so. He may with equal riglt dispose of all his property in favor of charities provided lie leaves no heirs at law. It is only when he leaves such heirs that his power of disposition by will is restricted. But this is not by reason of any public policy of this state against dispositions in favor of charity. In fact, the state lias no such public policy. It is well settled liere that dispositions to cliarity are looked upon with favor and the courts will uphold all sucl gifts whether made by a donor in his hifetime or by a testator, when it can be done consistently with the rules of law. The theory of section 1313 is not to prevent charities from receiving testamentary gifts of property. It is not a mortmain statute; not an expression of a policy of the state against the accumulation of vast properties or the centralization of wealth in mortua manu. It was not designed to operate upon the capacity of corporations or institutions or individuals to take claritable testamentary gifts but solely as a limitation on the power of the testator to make them when he had legal heirs. It was not enacted for the public good or as a matter of state policy, but for the benefit exclusively of those named in it,-the heirs at law-and as a protection against liasty and improvident gifts to charity by a testator of lis entire estate to the exclusion of those who in the judgment of the legislature lad a better claim to lis bounty."

655 CAL. JUR. 9.

${ }^{6}$ Supra note 2.

67 Supra note 1, at 686-687, 115 Pac. at 244-245. Italics added. See text to notes 1,33 . 
THE HISTORY OF FORMER SECTION 1275 OF THE CIVIL CODE ${ }^{\text {OS }}$

The Civil Code of California 1872, provided in section 1275: "A testamentary disposition may be made to any person capable by law of taking the property so disposed of, except that no corporation can take under a will, unless expressly authorized by statute so to take." The marginal title of this section which appears in the Code of 1872 is "Who may take by will." This statute, forbidding corporations to take under a will, unless expressly authorized by law, would appear to some, on casual perusal to suggest a Mortmain Policy; but when we consider first, that it refers entirely to wills and does not attempt in any way to limit the general capacity of corporations to take by other methods, and second, that it was not passed in any spirit of hostility to corporations, but solely for the benefit of the heirs-at-law of testators, we cannot argue that it was ever intended as a Mortmain Statute im any sense of the word. The truth of this statement will become more apparent as we proceed. The language of this section would not, it seems, have prevented a testator from bequeathing or devising to charitable uses but only to corporations.

During the twentieth session of the legislature, 1873-1874, numerous amendments to the Civil Code were passed. Among the statutes amended was section 1275 of the Civil Code which was changed to read: "A testamentary disposition may be made to any person capable by law of taking the property so disposed of, except corporations other than those formed for scientific, literary, or solely educational purposes, cannot take under a will, unless expressly authorized by statute. Effective immediately. Approved January 29, 1874." The marginal title appearing in the code at this time is "Who may take by will." This is the same marginal title that appeared with this section in the code of 1872 . The amendment, occurring so soon after the original code was promulgated, would seem to mdicate that the legislative will of the people had not been clearly expressed by section 1275 of the Code of 1872 . At all events it quickly becomes manifest that the intent of the people of California was to exempt from the terms of the statute certain types of corporations, and as above suggested, charitable uses. This conclusion is borne out when we consider that in the same session of the legislature, less than two nonths after the amendment to section 1275 of the Civil Code, section 1313 of the Civil Code was passed. This new section read:"0 "No estate, real or personal, shall be bequeathed or devised to any charitable or benevolent society, or corporation, or to any person or persons in trust for charitable uses, except the same be done by will duly executed at least thirty days before the decease of the testator; and if so

68 See Cal. Prob. Code $\S 27$.

69 Italics added. 
made, at least thirty days prior to such death, such devise or legacy, and each of them, shall be valid; provided, that no such devises or bequests shall collectively exceed one-third of the estate of the testator leaving legal heirs, and in such case a pro-rata deduction from such devises or bequests shall be made so as to reduce the aggregate thereof to one-third of such estate; and all dispositions of property made contrary thereto shall be void, and go to the residuary legatee or devisee, next of kin, or heirs, according to law. Approved March 18, 1874. Immediate effect." This section bears the marginal title in the code of that year: "Restriction of power to device to charitable uses." The language of this section would seem to imply either that at the time of its passage, and tion would seem to imply either that at the time of its passage, and possibly prior thereto, testators, under our law, were free to devise or bequeath to charitable or benevolent societies and corporations, or that by providing a himitation as to amount and time of disposition in these types of gifts, it bifted by implication, any prior restraints on testators' dispository powers in this regard. A few years after the passage of this statute, it was held in the Estate of Tobin ${ }^{70}$ that section 1313 of the Civil Code qualified the terms of section 1275 of the Civil Code and that charitable and benevolent societies and corporations might take by will. It is well at this time to bear in mind the remarks in the notes to Jarman on Wills, chapter 9, entitled "Restraints on Testamentary Power," to the effect that restraints of this type are generally considered restrictions upon the testator rather than upon the corporation. ${ }^{71}$ In 1903 section 1275 of the Civil Code was amended by including hospitals in the exception. In 1905 it was further amended by including in the exception, counties and mumicipalities, and by enacting that all dispositions thereunder should be subject to the provisions of section 1313 of the Civil Code. A further amendment in 1923 added to the exception, corporations formed primarily for the public preservation of forests and natural scenery. In 1931 section 1275 was repealed by the Probate Code and section 27 of that code is said to replace it. In this same year there appears in the General Corporation Law, section 341 of the Civil Code, which provides: "Every corporation heretofore or hereafter orgamized has power (3) to acquire, hold, lease, encumber, convey or otherwise dispose of real and personal property within or without the state and to take real and/or personal property by will, gift or bequest."72

Section 27 of the Probate Code reads: "A testamentary disposition may be made to the state, to counties, to municipal corporations, to natural persons capable by law of taking the property, to unincorporated

70 (1877) 1 Myrick Prob. Rep. 134.

71 See text to note 48 , supra.

72 Italics added. See text to notes $31,32,33$. 
religious, benevolent or fraternal societies or associations or lodges or brancles thereof, and to corporations formed for religious, scientific, literary or solely educational or hospital or sanatorium purposes, or primarily for the preservation of forests and natural scenery, or to maintain public bibraries, museums or art galleries, or for similar public purposes. No other corporation can take under a will, unless expressly authorized by statute." 33 It would seem that section 341 of the Civil Code places trading corporations or corporations in general on a more favorable basis than those corporations mentioned in section 27 of the Probate Code, unless section 341 of the Civil Code be considered a modification of section 27 of the Probate Code. The former interpretation would seem to be discriminatory, the latter fair and just, since we have in California no Statutes of Mortmain and no Mortmain Policy..$^{74}$

THE HISTORY OF FORMER SECTION 1313 OF THE CIVIL CODE ${ }^{75}$

In 1917 former section 1313 of the Civil Code was amended by excepting from its restrictions bequests and devises to the state or to any state institution or for the use or benefit of the state or any state institution. In 1919 educational institutions exempt from taxation under the constitution of the state were excepted froin the restrictions of the section, and a proviso added that the section should not apply to bequests or devises unade by will executed at least six months prior to the death of the testator, who leaves no parent, husband, wife, child or grandchild, or when all of such heirs shall have by writing, executed at least six months prior to his death, waived the restrictions contained therein. In 1925 municipahties, counties, and political subdivisions within the state were excepted from the restrictions of the statute. In 1929 the section was again amended, and the amendment in the second proviso at the beginning, in the place of the former provision, enacted the following: "that bequests and devises to and for the use or benefit of the state, or any inunicipality, county, or political subdivision within the state or any institution belonging to the state or belonging to any inunicipality, county or political subdivision within the state, or to any educational institution which is exempt from taxation under the State Constitution, ..." In 1931 former section 1313 of the Civil Code was repealed by the Probate Code, and we inust now look to sections 41, 42, and 43 of the Probate Code for the law on these points. Section 41 restricts the testator's power of disposing to charitable or benevolent societies, or corporations, or charitable uses, where he is survived by certain heirs, by limiting the time within

73 Italics added.

74 See text to note 33, supra.

75 See CaI. Prob. Code $\$ \S 41,42,43$. 
which the will must be made and by limiting the amount bequeathed or devised. Clearly this is a restraint only upon the testamentary power of disposition and not upon the capacity of devisees or legatees to take. Section 42 provides that the restraints shall not apply to certain corporations, nor when the testator is not survived by the heirs set forth in section 41 of the Probate Code. Section 43 of the Probate Code provides that the restraints set forth in section 41 of the Probate Code shall not apply (1) to wills executed six months before death, if the testator has none of the heirs mentioned in section 41 of the Probate Code; or (2) if having such heirs, they have all waived their rights under the section six months prior to his death. As these sections stand, they are all to be taken from their very clear terms as limitations only upon the testator's power of disposition and not upon the capacity of charitable devisees or legatees to receive. Any doubt upon this point is well settled by the language of section 43 of the Probate Code. It is therefore evident that these sections are not intended to be interpreted as Statutes of Mortunain but are desigued solely to protect lieirs of the testator. ${ }^{76}$

\section{LAWFUL MIEANS OF GIVING TO CHARITABLE ORGANIZATIONS REGARDLESS OF RESTRICTIONS OF FORMER SECTION \\ 1313 OF THE CIVIL CODE AND OF SECTION 41 OF THE PROBATE CODE}

The provision of the code which limits the right to bequeath or devise property to, or in trust for, charitable or benevolent purposes does not apply to disposition of property by deed. Nor will a deed for that purpose be construed as a fraud upon the statute, although the grantor reserves the right to revoke or modify the saine for a period of years.77 Since a deed may be made at any time, so long as the grantor has the capacity, it follows that a death-bed deed might be just as effective a means of accomplishing a gift to charities as a last will and testannent, and yet it would not be subject to any of the limitations placed on the latter, either under former section 1313 of the Civil Code or under the present section 41 of the Probate Code.

THE INUTILITY OF FORMER SECTIONS 1275 AND 1313 OF THE CIVIL CODE OR OF STMILAR STATUTES OF THE PROBATE CODE

In this state it seems there was never any need of such restrictions as those contained in the former sections 1275 and 1313 of the Civil Code or of similar statutes of the Probate Code for the following reasons: (1) Since these sections have never been applicable to deeds or death-bed

${ }^{76}$ See Estate of Lennon; Estate of Hamilton, both supra note 60; Estate of Dwyer, supra note I.

77 President etc. of Bowdoin College v. Merritt, supra note 2. Cf. 9 Cat. JUR. 218. 
deeds, it has always been lawful to accomplish by an equally convenient method (by deed), the very same purpose which they prevent a testator from accomplishing by will. (2) There has never been any Mortmain Policy in this state. (3) From the paucity of cases on this topic, experience has not shown that testators are prone to disinherit their immediate heirs and leave their entire estates to charities. (4) If the legislature had the protection of heirs in view in passing these enactments it should not have omitted revocable deeds or death-bed deeds from the law apphicable to the situation.

\section{THE PRESENT STATUS OF THE LAW BY REASON OF THE 1937} AMENDMENT TO SECTION 42 OF THE PROBATE CODE

This year the legislature amended section 41 of the Probate Code, and instead of the phrase "legal heirs," we now have listed therein: the surviving spouse and certain close relatives, lineal and collateral, namely, brothers, sisters, nephews, nieces, descendants and ancestors. Section 42 of the Probate Code was also amended so as to exempt from the restrictions of the article, i.e., from the himitations as to amount and time of testamentary dispositions, all corporations organized under section 606 of the Civil Code. That section by its own terms, originally made all corporations thereunder subject to these limitations by providing that they should take under the restrictions set forth in former section 1313 of the Civil Code. Since former section 1313 of the Civil Code has been repealed, we inust conclude that the legislature has manifested its intent that the corporations enumerated in section 606 of the Civil Code shall be exempt from all these restrictions, (1) because section 42 of the Probate Code now classifies these types of corporations with the sovereign state and her various political subdivisions, and expressly exempts them from all limitations as to the time within which testamentary dispositions may be made to them and also as to the amount of such dispositions; and (2) because former section 1313 of the Civil Code has been repealed, and as such does not exist. Hence, section 606 of the Civil Code may no longer be regarded as having any of its provisions limited by the restraints as to the time or amount of the bequest or devise. From this it follows that the restrictions of section 41 of the Probate Code may now be defeated by will, if one leaves lis land or money to a corporation organized under section 606 of the Civil Code, for the benefit of the corporation to which he may not devise or bequeath under section 27 of the Probate Code, except subject to the limitations of section 41 of the Probate Code. Therefore a donor may now (1) give directly to any charity at any time and in any amount by deed (including deatll-bed deed) with or without power of revocation; (2) give indirectly to any charity 
at any time and in any amount by will if the bequest or devise is made to any corporation organized under section 606 of the Civil Code, regardless of any distinctions or restrictions contained in sections 27 and 41 of the Probate Code; and yet a donor may not give directly by will to any charity except under the distinctions and limitations provided by sections 27 and 41 of the Probate Code. The 1937 amendment to section 42 of the Probate Code makes the himitations of section 41 seem useless and the distinctions of sections 27 and 43 unnecessary.

Briefly the case is this: During many years successive legislatures have, with great effort, expanded codal exceptions permitting testators to give and certain types of corporations to take by will, granted immunities to some corporations by exempting them from the restrictions as to amount and time of bequests and devises, and denied these same immunities to others, all under the theory of protecting the heirs-at-law. To climax these noble efforts of the past, our recent legislature has just gone into "labor" and brought forth a new, 1937 nodel of subtlety, in the form of a cumbersome, involved, indirect method of giving by will to clarity, without the limitations inposed by section 41 of the Probate Code. If there is anything that may be heralded as an utterly useless technicality, capable of incubating a host of artificial distinctions, it seems to be this newest progeny of "mother legislature." Such an outstanding example of technicality for technicality's sake is a refinement so choicely cryptic and so nianifestly unnecessary that it will not only surprise seasoned practitioners, familiar with this departnent of the law, but it will unost likely astound neembers of the bar who may not yet have lad the occasion to delve into these intricacies to discover this carefully hidden method of aiding charitable beneficiaries to take by bequest and devise. It may be argued that an attorney, practicing law in California, should be thoroughly acquainted with our technical statutes, and that he is, in duty, bound to familiarize hiniself with them, one and all, regardless of their latent wiles. This is undoubtedly true; but it is very questionable froin a practical view point, first, if a majority of our profession, after an ordinary reading of the statutes, would be aware of this novel subtlety; second, if a majority of our profession, assuming their willinguess and mental agility, would have enough time to devote to a legal fox-hunt for the purpose of discovering it; and, third, if the true function of a legislature is to beget such an offspring in this enlightened epoch. Since section 40 of the Probate Code provides that all dispositions by will, whether made in or out of this state, are subject to the provisions of the act limiting charitable bequests and devises, it might be well to ask ourselves if the type of legislation we have been considering is fair to the attorneys in other jurisdictions, who in drafting wills, either for clients from Califorma or for clients from their own states, 
may be required to name as beneficiaries, certain charitable organizations $i \mathrm{u}$ the state of California. Is it reasonable to suppose that these attorneys would be sufficiently suspicious to look for such strange distinctions in our laws? Last, but most important of all, there is that vast number of individuals, the citizens of our state, for whose benefit all laws are said to be passed, who must be most carefully considered in this problem. How many of them could ever be expected to discern the import of these statutes even if they read them? How many would endorse the novel technicality which we have been discussing? Why should testators wishing to leave to charitable orgamizations be confounded with a series of black magic distinctions, which if observed, will make valid their gifts to the full extent of their estates, but which if not observed, will reduce their bequests or devises to one-third? If a donor has always been able to avoid directly by deed ${ }^{78}$ the limitations of section 41 of the Probate Code and if he is now able indirectly to evade them by will, ${ }^{70}$ what possible reason can be advanced for their continued existence?

What useful purpose is accomplished by forcing the donor or his attorney to roam through these various labyrinths of legislative haze in order to discover the charmed method by which he may do directly by deed, but only indirectly by will, what he should always have been able to do directly by will according to the policy of this state?

Therefore, the legislature should either inject into these statutes some element of utility and of coordination or else repeal them all. It seems, however, after our analysis of these laws and of the policy which prompted their enactment, that the only true solution of the problem lies in a complete repeal; so that by a single act, all the artificial and ineffectual restraints imposed upon a donor's free disposition of his property by will, may forever be abohished.

\section{J. Brent Bodfish.}

SchOOL OF LaW,

UNIVERSITY of SAN Francisco

78 President etc. of Bowdoin College v. Merritt, supra note 2.

79 Cas. Prob. Code $\S 42$. 